
\title{
$\begin{array}{ll}\text { Research Square } & \begin{array}{l}\text { They should not be considered conclusive, used to inform clinical practice, } \\ \text { or referenced by the media as validated information. }\end{array}\end{array}$ \\ Factors Impacting University-Industry Collaboration in European Countries
}

Bojan Cudic ( $\sim$ bojan.cudic@um.si )

University of Maribor https://orcid.org/0000-0002-7884-0419

\section{Peter Alešnik}

University of Maribor

David Hazemali

University of Maribor

\section{Research}

Keywords: university-industry collaboration, Europe, knowledge, networking, R\&D, PLS-SEM

Posted Date: August 17th, 2021

DOl: https://doi.org/10.21203/rs.3.rs-783478/v1

License: (1) This work is licensed under a Creative Commons Attribution 4.0 International License.

Read Full License 


\title{
Factors Impacting University-Industry Collaboration in European Countries
}

Bojan Ćudić, bojan.cudic@um.si

Peter Alešnik, peter.alesnik@um.si

David Hazemali, david.hazemali1@um.si

\begin{abstract}
This paper aims to examine the links between university-industry collaboration (UIC) predictors (inputs), and the results of UIC cooperation (outputs). The focus of the research is UIC within the European Union member states and the Western Balkan countries.

The analysis was conducted using the partial least squares structural equation modeling (PLSSEM). This method enabled examining the links between variables that are not directly observable. The authors used data for the period of three years, 2015-2018. The results prove that countries investing in UIC predictors (inputs) have better UIC performance (outputs). Based on the statistical analysis, the authors identified the investments in knowledge, networking, and research and development $(\mathrm{R} \& \mathrm{D})$, in general, as the most significant that impact UIC performance.
\end{abstract}

Keywords: university-industry collaboration; Europe, knowledge; networking; R\&D; PLS-SEM

\section{Introduction}

In recent decades, researchers have been intrigued by the ever-increasing importance of universityindustry collaboration (UIC), in particular by the factors of its success (Hillebrand and Biemans 2003; Parkhe 1993). UIC is emerging as a critical component of the innovation process. It is a vital component of the regional innovation policy-mix for regional policymakers as the successful exploitation of $R \& D$ results is fundamental for regional competitiveness (Morisson and Pattinson 2020).

A noticeable shift towards regionalization in innovation policy and technology is evident. One of its consequences is the expectation for universities to draft networks and establish regional ties (Koschatzky and Stahlecker 2010). Also of considerable importance is the construction of broad collaborative cluster networks, although most clusters focus on loosely defined local level networks. Notwithstanding, network members are responsible for more patent applications than others. What is more, there seems to be no loss of patent quality when collaborating with same cluster region universities (Nishimura and Okamuro 2010).

UIC is mostly based on knowledge and technology transfer. Philbin notes that there is much evidence for a strong correlation between technology transfer and practical knowledge on the one side, and successful collaboration on the other (Philbin 2010). An intense transfer can improve the technology novelty (Guan et al. 2005), encourage innovation performance (MingJi and Ping 2014), and/or boost product development (Fernandes and Ferreira 2013). Nevertheless, many barriers impact knowledge and technology transfer, and this is a topic of many pieces of research (see de Medeiros et al. 2012; Hong et al. 2010; Schofield 2013). In their study from 2009, Flores et al. state that technology transfer and knowledge are influenced by strategy and motivation (Flores et al. 2009), where utilization of adequate policies and incentives can enhance transfer activities in UIC (Schofield 2013). Knowledge transfers might be impacted differently by universities and companies. While the former initiate knowledge transfer through research, the latter take on more managerial positions afterward (Goel et al. 2017). 
To investigate factors that impact UIC, the authors used data provided by the Global Innovation Index (GII). The Innovation Input Sub-Index and the Innovation Output Sub-Index - each constructed around pillars, are two sub-indices the GII relies on. In the Innovation Input SubIndex, elements of the national economy that enable innovative activities are captured by five input pillars. The five input pillars are business sophistication, market sophistication, infrastructure, human capital and research, and institutions. The Innovation Output Sub-Index encompasses innovation outputs, which stem from innovative activities within the economy. The output pillars are creative outputs, and knowledge and technology outputs. The average of the Input and Output sub-indices marks the overall GII score. (Cornell University, INSEAD, and WIPO 2010-2020).

Based on the defined elements, the authors created groups of factors that influence UIC (impact factors). On the other hand, the UIC performance level in a specific country is measured by the set of output factors. The differences in approach to the support of UIC also lead to companies achieving different results. This motivated the authors to explore the main factors that impact UIC in European countries. Thus, this article intends to answer the following question: "What are the vital factors that influence UIC"?

\section{Literature Review}

Many articles deal with the factors that make UIC successful. Rybnicek and Königsgruber (2019) conducted a thorough, in-depth review of the published scholarly literature on industry-university collaboration. They performed an extensive analysis of UIC projects' research to distil factors that influence such partnerships' success. Given the comprehensiveness of this research, as the authors of this paper used it as a base for identifying factors that determine UIC. Many other authors also deal with this topic, and the most recent and relevant articles are presented in this part of the research.

Based on the review of the existing literature, the authors could organize the factors that determine UIC. They are marked as "input factors" in the article and deployed into four categories. Firstly, there are institutional factors, which refer to business environment and government effectiveness. Secondly, there are human factors, which refer to human capital and research. Thirdly, there are linkage factors, which refer to relationships between universities and companies. Fourthly, there are framework factors, which refer to the business infrastructure. Finally, the authors define "output factors" that presents the level of UIC in a specific country.

\section{Institutional Factors}

Institutional factors include the business environment, legal restrictions, and/or governmental support. Kozlinska defines the government as an influential power with the ability to either facilitate or harm collaboration (Kozlinska 2012). On the one hand, the governmental network (Rampersad 2015), public funding (e.g., Piva and Rossi-Lamastra 2013; Flores et al. 2009), or tax incentives (Bodas Freitas et al. 2013) can facilitate UIC. On the other hand, the absence of regional bracing structures (Şerbănică 2011), and/or regulations and legal restrictions (Hadjimanolis 2006; Attia 2015; Arvanitis et al. 2008) can have a negative impact on collaboration. As a rule, industryuniversity partnerships rely heavily on governmental support (e.g., Newberg and Dunn 2002; Myoken 2013; Collier et al. 2011; Sohal 2013; de Medeiros et al. 2012; Muscio and Vallanti 2014; Schofield 2013; Hemmert et al. 2014). Additional factors of business environmental success correspond to the market potential of research results (Barnes et al. 2002; Hadjimanolis 2006; Guan et al. 2005; Ankrah and AL-Tabbaa 2015) or market uncertainties (Hemmert et al. 2014). 


\section{Human Factors}

Human resources play a vital role in the successful implementation of university-industry projects (Albats et al. 2020). Normally, there exists a strong dependence of the utility and quality of collaboration on the partner's available resources. The need for specific resources further limits the scope of potential partners (Ferru 2010). For successful collaboration, highly qualified human resources (Myoken 2013) are paramount. Also, of significance are unrestricted access to libraries, lab space, and similar infrastructure (Boardman and Bozeman 2015); and/or technical equipment (Arvanitis et al. 2008). Companies with better-educated and/or more knowledgeable managers/supervisors tend to innovate more (Marotta 2007). In his analysis of a survey of 39,336 enterprises, Merrit (2015) argues that larger enterprises due to a higher level of human capital can harness university-driven and generated knowledge more efficiently than smaller enterprises. The latter are less capable of absorbing said knowledge since they generally lack qualified technicians and engineers who are invaluable for innovation endeavors.

\section{Linkage Factors}

In the research, linkage factors refer to gross domestic expenditure on R\&D (GERD) performed by an enterprise, GERD financed by a business enterprise, university-industry research collaboration, the state of cluster development, GERD financed from abroad, and by joint venture/strategic alliance deals. Working together and implementing each other's experience and feedback in the pursuit of improvements has been proven beneficial for both universities and companies (Ryan 2009). Albats et al. argue that the preeminent aspect of a company's strategy in the shaping of their innovation performance is the creation of strategic partnerships, in particular university partnerships. (Albats et al. 2020). The impact of communication is thoroughly examined in the addressed literature. We ought to emphasize that to establish a shared understanding, communication frequency is paramount (Hong et al. 2010; Lee 2011). Close personal relationships also enable crucial links between universities and companies (Barnes et al. 2002; Collier et al. 2011). Contacts and actions ought to be on the operational level (regular interaction, mutual exchange of information with continuous feedback, and updating partners on new activities or incidents) and encompass the management level (Wu 2017). Guan et al. regard the absence of communication channels as the primary barrier in partnerships (Guan et al. 2005). Also beneficial for the establishment of positive expectations about the partner's future behavior (especially when the partnership is still fresh) is reciprocal communication (accurate, adequate, timely, and regular) (Bstieler et al. 2017). Finally, we must also consider the role of culture in UICs. The latter is defined as the mutual understanding within a company on how employees ought to view, feel and think about issues and challenges (Schein 2004).

\section{Framework Factors}

In the research, the linkage factors refer to ICT access, ICT use, electricity output, logistics performance, gross capital formation, environmental performance, and the rule of law. Nishimura and Okamuro (2010) explained that UIC's legal aspects and intellectual property rights (IPRs) are significant. The IPR policy of governments and universities has a positive and significant impact on UIC project performances, controlling for firm and project characteristics and considering potential selection bias from UIC participation. Betz et al. (2010) state that a favorable business environment does not, by default, affect the university's technology transfer activities positively. It is the implemented strategy of each university that is much more important than the 
environmental factors. Nevertheless, with an overall improvement in R\&D capability, R\&D collaboration, and technology, commercialization will also be enhanced (Vea 2014).

The results demonstrate that increased attention to technology $R \& D$ and the protection of patents by governments and companies has led to immense improvements in the ICT sector. What is more, companies have now become the main body of technological innovation (Xia et al. 2014). Yarmouk University has developed dynamic programs of ICT enrichment and adopted an innovative partnership model, which in the form of an on-campus facility seeks to bridge the academia-industry gap. The facility offers a productive, internal collaborative environment for technical and business faculties, which together pursue projects to cultivate collaboration with industrial and business partners. Moreover, it facilitates the alignment of skills and knowledge of university staff and students to contemporary real industry needs, and updates the university's knowledge base with the latest industry developments (Al-Agtash and Al-Fahoum 2008).

\section{Output Factors}

In the literature, there are many performance indicators of UIC. The number of patents (Xia et al. 2014), scientific and technical articles (Salimi and Rezaei 2016), high-tech manufactures and exports (Aiello et al. 2019), intellectual property receipts (Valentin and Jensen 2007), ICT services exports (D’Costa 2006; Hwang 2020), cultural and creative services exports (Draghici et al. 2016), creative goods exports (Banal-Estañol et al. 2011), are frequently mentioned. In general, the output indicators can be divided into two groups: tangible and intangible.

As Rybnicek and Königsgruber (2019) stated, the compatibility of partner-to-partner goals is among the most discussed subjects in UICI literature. Failure to achieve the desired outcome is often the result of incompatibility (Henderson et al. 2006). For example, companies strive towards withholding the groundbreaking findings from universities from competitors, while the universities desire to publish them (Newberg and Dunn 2002). Lai and Lu provide similar results (2016). They state that companies and universities strive towards different goals. Consequently, it is paramount to seek a win-win situation with balanced benefits for both partners. This can be achieved only if both partners understand the other's interests. Also essential is for partners to agree upon achievable goals through a shared understanding of the objectives, and to materialize a precise strategy throughout the collaboration (Hong et al. 2010). It should also be added that partners more often than not hold unrealistic expectations about the outcome of cooperation, and/or have a different sense of urgency (Attia 2015).

For the purpose of finding the appropriate partner, a correct partner selection process is advised prior to collaboration. In this sense, confidence in one's own needs and requirements is also a prerequisite. Only then can the search for an adequate partner with concordant interests and goals begin (Arvanitis et al. 2008). Adequate search strategies can facilitate the search for a matching partner. Barnes et al. (2002) recommend a partner evaluation method with specific criteria.

\section{Methodology}

\section{Construct Measures}

The authors have grounded the theoretical framework of this article in a systematic review of relevant scholarly literature while also considering the availability of the variables' data. At the outset, we elicited 36 measures. These were grouped into six constructs, four of which focus on input factors, the remaining two on output factors. We depicted the research model in Figure 1. 
Table 1 Factor measures and data source

\begin{tabular}{|c|c|c|c|}
\hline Construct & Measure & Code & Data source \\
\hline \multirow[t]{7}{*}{ Institutional factors } & & IIF & \\
\hline & Political and operational stability & IIF1 & \\
\hline & Government effectiveness & IIF2 & \\
\hline & Regulatory quality & IIF3 & \\
\hline & Ease of starting a business & IIF4 & \\
\hline & Gross expenditure on R\&D (GERD) & IIF5 & \\
\hline & Expenditure on education & IIF6 & \\
\hline \multirow[t]{7}{*}{ Human factors } & & IHF & \\
\hline & PISA scales in reading, math, \& science & IHF1 & \\
\hline & Graduates in science \& engineering & IHF2 & \\
\hline & Tertiary level inbound mobility & IHF3 & \\
\hline & Researchers, full-time equivalent & IHF4 & \\
\hline & $\begin{array}{l}\text { / Million population } \\
\text { Employment in knowledge-intensive services }\end{array}$ & IHF5 & \\
\hline & Research talent in business enterprise & IHF6 & \\
\hline \multirow[t]{6}{*}{ Linkage factors } & & ILF & \\
\hline & GERD performed by business enterprise & ILF1 & \\
\hline & GERD financed by business enterprise & ILF2 & \\
\hline & University-industry research collaboration & ILF3 & \\
\hline & State of cluster development & ILF4 & \\
\hline & Joint venture/strategic alliance deals & ILF5 & \\
\hline \multirow[t]{8}{*}{ Framework factors } & & IFF & World Intellectual \\
\hline & ICT access & IFF1 & Property Organization \\
\hline & ICT use & IFF2 & (WIPO), 2015-2018 \\
\hline & Electricity output, $\mathrm{kWh} / \mathrm{mn}$ pop. & IFF3 & \\
\hline & Logistics performance & IFF4 & \\
\hline & Gross capital formation & IFF5 & \\
\hline & Environmental performance & IFF6 & \\
\hline & The rule of law & IFF7 & \\
\hline \multicolumn{2}{|c|}{ Output intangible indicators } & OII & \\
\hline & Patent applications by origin & OII1 & \\
\hline & Patent Cooperation Treaty (PCT) & OII2 & \\
\hline & Scientific and technical publications & OII3 & \\
\hline & Trademark application class count by origin & OII4 & \\
\hline & Industrial designs by origin & OII5 & \\
\hline & ICTs and business model creation & OII6 & \\
\hline \multicolumn{2}{|c|}{ Output tangible indicators } & OTI & \\
\hline & Cultural and creative services exports & OTI1 & \\
\hline & Creative goods exports & OTI2 & \\
\hline & $\begin{array}{l}\text { The growth rate of Gross domestic product (GDP) per person } \\
\text { engaged }\end{array}$ & OTI3 & \\
\hline & High-tech and medium high-tech output & OTI4 & \\
\hline & New business density & OTI5 & \\
\hline
\end{tabular}

Figure 1 depicts the model' schematic diagram. Both the internal and external relationships were considered. ${ }^{1}$ The estimation was conducted with the help of SmartPLS software.

\footnotetext{
${ }^{1}$ Internal model relationships are represented by the solid line, while the broken line was used for the external model relationships.
} 


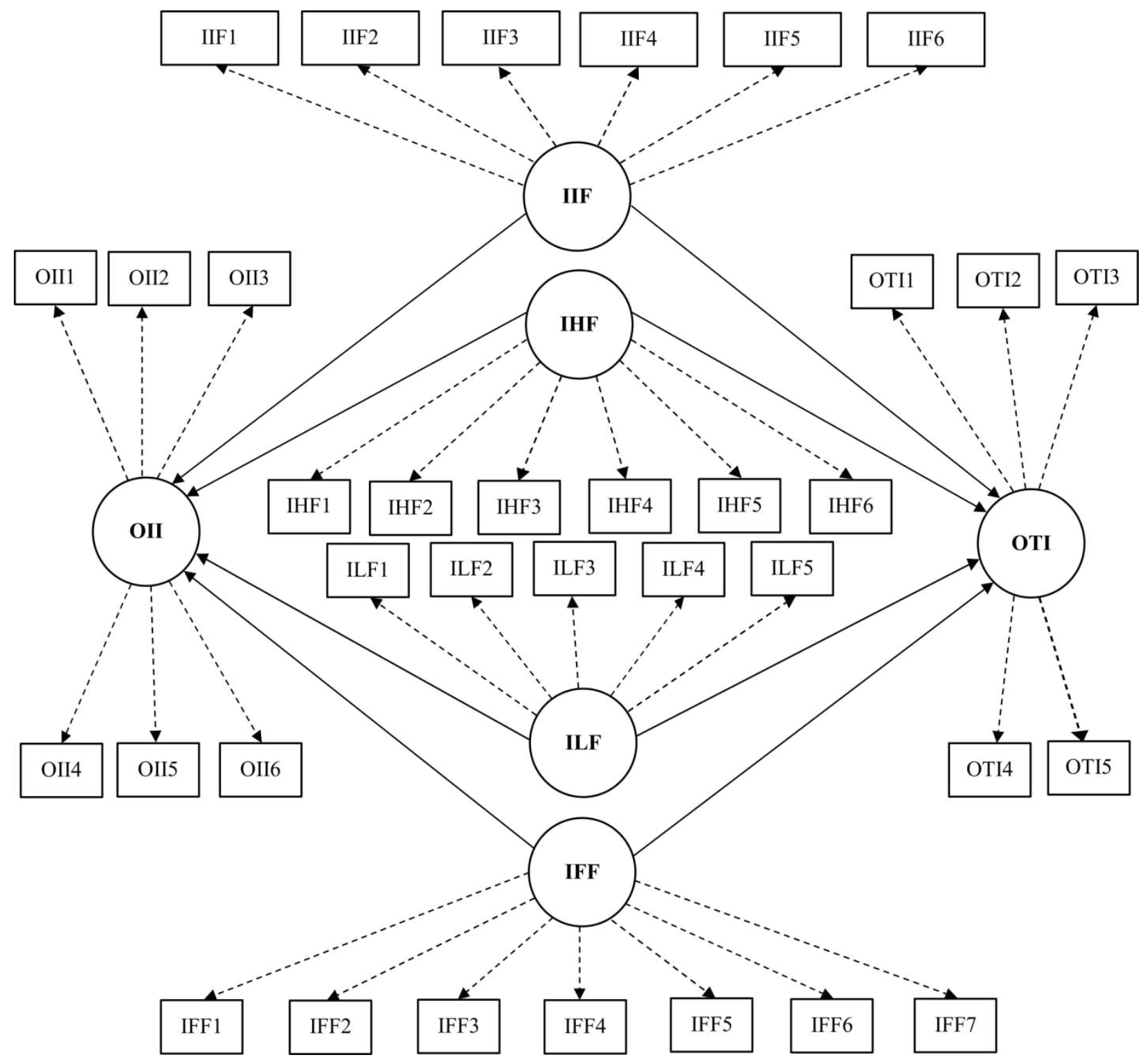

Fig. 1 Schematic diagram of internal and external relationships of the model

\section{Research Method}

This research uses the structural equation modeling method (SEM). SEM encompasses a plethora of statistical methodologies by which a causal relationship's network can be approximated. A theoretical model defines such a network as one which links at least two latent complex concepts. Several observable indicators measure each of these concepts. In essence, we can study the complexity within a system by considering a causality network among latent concepts - "latent variables". Many observed indicators usually defined as "manifest variables" are used to measure each of these latent variables. According to this, structural equation models represent a joint-point between path analysis and confirmatory factor analysis (Esposito Vinzi et al. 2010). Among the 
methods of estimating SEM models, the covariance-based (CB) method ${ }^{2}$, invented by K. G. Jöreskog, enjoyed the greatest popularity for a long time. So universal was its recognition that in social sciences the phrases: SEM and covariance-based structural equation modeling (CB-SEM) were synonymous for many years (Chin et al. 1996). Meanwhile, H. Wold developed an alternative approach - the partial least square method (PLS). Its description and application for estimating models with latent variables were presented by Wold in, among others: (Wold 1979, 1980b, 1980a). Because the PLS method was an alternative to K. G. Jöreskog's 'hard' modelling, i.e. one based on strong assumptions regarding the normality of distributions and requiring large samples, Wold referred to his PLS approach as 'soft' modelling (Wold 1980b, 1982). After a time, the term 'PLS-path modelling'. ${ }^{3}$ Came into use, and then - in order to emphasize that PLS was an alternative to $\mathrm{CB}$, it began to be called 'PLS Structural Equation Modeling' (PLS-SEM).

PLS-SEM and CB-SEM were developed as distinct, though complementary, methods with specific purposes and requirements. This was clearly stressed by the authors of both approaches at the beginning of the 1980s (Jöreskog and Wold 1982). At present, the varying properties of PLSSEM and CB-SEM are also noticed, with emphasis on the complementarity of the two methods instead of the competition between them. The advantages of the non-parameter, variance-based PLS-SEM modelling are, at the same time, the disadvantages of the parameter, covariance-based CB-SEM - and the other way around. Therefore, the choice of method should depend on the empirical context and research purposes (Hair et al. 2019).

An SEM model consists of two sub-models: a structural one and a measurement one. In PLSSEM terminology, the phrases' inner model' and 'outer model', respectively, are also used. A structural model describes the relationships among latent variables, whereas a measurement model - the relationships among the latent variables and the indicators by which they are identified, also known as manifested variables (Wold 1980a).

When constructing a structural model, one must pay particular attention to two aspects: the nature of the analyzed latent variables and the associations which occur among them. It is important to distinguish between exogenous variables and endogenous ones. Furthermore, all the formulated elements of the conceptual framework should be derived from theory and logic. If a theoretical basis is lacking, or if the theory is inconsistent, one should rely on one's own judgment, experience, and intuition (Hair et al. 2017).

Specification of the measurement model is an equally important stage of the modeling process. Verification of the hypotheses reflected in the structural model's equations can be reliable when, and only when, the latent variables are correctly defined by means of indicators. And the choice of indicators is as crucial as the choice of the way in which they are defined (Hair et al. 2017). Definition of latent variables by means of indicators can be done either deductively or inductively (Rogowski 1990). Under the former approach, indicators reflect the defined latent variable and are then referred to as reflective indicators, while the measurement model is called a reflective measurement model. In the case of inductive definition, it is assumed that indicators make up the latent variables, hence the expressions formative indicators and formative measurement model. The type of definition (inductive or deductive) should follow from the assumed theoretical description (Rogowski 1990). Also, the choice of observable indicators should be preceded by an

\footnotetext{
${ }^{2}$ In the CB-SEM method, a theoretical covariance matrix is estimated on the basis of a structural equations model. The estimation of model parameters is performed in such a way as to minimize the difference between the theoretical covariance matrix and the estimated covariance matrix.

${ }^{3}$ Among other things, in order to distinguish models containing latent variables estimated by means of the PLS method from PLSbased regression. Even now, in many publications, authors confuse the work of H. Wold and that of S. Wold.
} 
in-depth and thorough literature review, including the theory and empirical studies in measuring the latent variables present in the model.

Alongside examining latent variables' correlations, PLS-SEM modeling also helps approximate the values of said variables (weighted sums of indicators). For that reason, a synthetic measurement, with which we can obtain a linear ordering of the studied objects, is calculated for each of the model's latent variables.

Estimation of a PLS-SEM model is performed using the PLS method. The algorithm simultaneously estimates inner model parameters - path coefficients - and outer model parameters - outer weights and outer loadings. The procedure also yields estimations of the values of all the latent variables included in the model. The estimation aims to maximize the explained variance of the latent dependent variables. The first stage involves the iterative estimation of measurement model weights and the values of latent variables. At the second stage, the loadings and path coefficients of the structural model are estimated. A detailed description of the PLS algorithm can be found, e.g. in (Henseler et al. 2012; Wold 1982), and its generalization in (Rogowski 1990).

Verification of a PLS-SEM model is a two-stage process. First, the structural model is assessed. Second, if the validity of the structural model has been confirmed, the structural model is tested. Table 2 lists the properties of the model, which should undergo evaluation.

Table 2 Evaluation of PLS-SEM models

\begin{tabular}{|c|c|c|c|c|c|c|}
\hline \multicolumn{7}{|c|}{ Evaluation of the measurement models } \\
\hline \multicolumn{4}{|c|}{ Reflective measurement models } & \multicolumn{3}{|c|}{$\begin{array}{c}\text { Formative measurement models } \\
\end{array}$} \\
\hline \multirow{2}{*}{$\begin{array}{l}\text { Internal } \\
\text { consistency }\end{array}$} & \multicolumn{2}{|c|}{ Cronbach's alpha } & $0.60-0.95$ & \multirow{2}{*}{$\begin{array}{l}\text { Convergent } \\
\text { validity }\end{array}$} & \multirow{2}{*}{ Redundancy analysis } & \multirow{2}{*}{$\begin{array}{c}\geq 0.7 \\
\text { correlation }\end{array}$} \\
\hline & Composite reliabi & & $0.60-0.95$ & & & \\
\hline \multirow{2}{*}{$\begin{array}{l}\text { Convergent } \\
\text { validity }\end{array}$} & \multicolumn{2}{|c|}{ I } & $\geq 0.7$ & \multirow{2}{*}{$\begin{array}{l}\text { Collinearity } \\
\text { between } \\
\text { indicators }\end{array}$} & \multirow{2}{*}{$\begin{array}{l}\text { Variance Inflation } \\
\text { Factor (VIF) }\end{array}$} & \multirow[b]{2}{*}{$\geq 0.5$} \\
\hline & \multicolumn{2}{|c|}{$\begin{array}{l}\text { The average variance } \\
\text { extracted (AVE) }\end{array}$} & $\geq 0.5$ & & & \\
\hline \multirow{3}{*}{$\begin{array}{l}\text { Discriminant } \\
\text { validity }\end{array}$} & \multicolumn{3}{|c|}{ Cross-loadings } & \multirow{3}{*}{$\begin{array}{l}\text { Significance } \\
\text { of outer } \\
\text { weights }\end{array}$} & \multirow{3}{*}{$p$-value } & \multirow{3}{*}{$<0.05$} \\
\hline & \multicolumn{3}{|c|}{ Fornell-Larcker criterion } & & & \\
\hline & \multicolumn{2}{|c|}{$\begin{array}{l}\text { Heterotrait-monotrait } \\
\text { ratio }(\mathrm{HTMT})\end{array}$} & $<0.9$ & & & \\
\hline \multicolumn{7}{|c|}{ Evaluation of the structural models } \\
\hline \multicolumn{2}{|l|}{ Collinearity } & \multicolumn{3}{|c|}{ VIF } & \multicolumn{2}{|c|}{$\geq 0.5$} \\
\hline \multicolumn{2}{|c|}{ Predictive power } & \multicolumn{3}{|c|}{ Coefficients of determinations $\left(R^{2}\right)$} & \multicolumn{2}{|c|}{$\begin{array}{c}\text { values of } 0.75,0.50 \text { and } 0.25 \text { are } \\
\text { considered substantial, moderate, and } \\
\text { weak }\end{array}$} \\
\hline \multicolumn{2}{|c|}{ Predictive relevance } & \multicolumn{3}{|c|}{ Stone-Geisser's $Q^{2}$ value } & \multicolumn{2}{|c|}{$\geq 0$} \\
\hline \multicolumn{2}{|c|}{ Significance of path coefficients } & \multicolumn{3}{|c|}{$p$-value } & \multicolumn{2}{|l|}{$<0.05$} \\
\hline
\end{tabular}

Source: authors' work based on Hair et al. (2017).

SEM using the PLS procedure used to be difficult due to the unavailability of software. Now the situation has greatly improved thanks to the wide range of user-friendly programs, which enable estimation and statistical verification of PLS-SEM models, e.g. WarpPLS (Kock 2020), ADANCO (Henseler and Dijkstra 2015), SmartPLS (Ringle et al. 2015). This study will use the SmartPLS software. 


\section{Specification of the Model}

The model used for the realization of the research objective, i.e., proving the influence of UIC predictors on UIC performance, contains Eqs. 1a and $1 \mathrm{~b}$.

$$
\begin{aligned}
& \mathrm{OTI}_{\mathrm{t}}=\alpha_{1} \mathrm{IIF}_{\mathrm{t}}+\alpha_{1} \mathrm{IHF}_{\mathrm{t}}+\alpha_{1} \mathrm{ILF}_{\mathrm{t}} \alpha_{1} \mathrm{IFF}_{\mathrm{t}}+\alpha_{0}+v_{\mathrm{t}} \\
& \mathrm{OII}_{\mathrm{t}}=\alpha_{1} \mathrm{IIF}_{\mathrm{t}}+\alpha_{1} \mathrm{IHF}_{\mathrm{t}}+\alpha_{1} \mathrm{ILF}_{\mathrm{t}+} \alpha_{1} \mathrm{IFF}_{\mathrm{t}}+\alpha_{0}+v_{\mathrm{t}}
\end{aligned}
$$

where:

$\mathrm{OTI}_{\mathrm{t}}-$ output tangible indicators in period $t$,

$\mathrm{OII}_{\mathrm{t}}-$ output intangible indicators in period $t$,

$\mathrm{IIF}_{\mathrm{t}}$ - institutional factors in period $t$

$\mathrm{IHF}_{\mathrm{t}}-$ human factors in period $t$

$\mathrm{ILF}_{\mathrm{t}}$ - linkage factors in period $t$

$\mathrm{IFF}_{\mathrm{t}}-$ framework factors in period $t$

$\alpha_{0}, \alpha_{1}-$ structural parameters of the model,

$v_{\mathrm{t}}-$ random component,

$t_{-}$Period of three years $2015-2018 .^{4}$

The authors used the deductive approach to defining latent variables in the model, i.e., each latent variable as a theoretical notion is a starting point for the search for empirical data. The indicators were selected based on substantive and statistical criteria. The following things were accounted for from the statistical perspective: indicator values' diversity, measured by the coefficient of variation (the coefficient's critical value was calculated at $10 \%$ ), and the quality of the estimated model (model evaluation measures - ex-post analysis). Table 3 presents the indicators that passed substantive and statistical verification. The indicators of the input latent variables point to the most frequent and significant predictors of the UIC. Meanwhile, the OTI and OII measures reflect the outputs of UIC.

\footnotetext{
4 The Program for International Student Assessment (PISA) results is one of the significant indicators in the model. The PISA test was conducted across OECD countries in 2015 and 2018, and that is the reason why the authors chose these two years to examine changes in variables.

${ }^{5}$ This is calculated as a ratio of the standard deviation to the arithmetic mean, expressed in percentage.
} 
Table 3 Indicators of latent variables qualified for the model

\begin{tabular}{|c|c|c|c|}
\hline $\begin{array}{l}\text { Latent } \\
\text { variables }\end{array}$ & Description of indicator & Code & Loadings \\
\hline \multicolumn{2}{|c|}{ Institutional factors } & \multicolumn{2}{|l|}{ IIF } \\
\hline & Political and operational stability & IIF1 & 0.843 \\
\hline & Government effectiveness & IIF2 & $0.975(\text { Omitted })^{*}$ \\
\hline & Regulatory quality & IIF3 & 0.945 (Omitted)* \\
\hline & Ease of starting a business & IIF4 & 0.479 (Omitted) \\
\hline & Gross expenditure on R\&D (GERD) & IIF5 & 0.889 \\
\hline & Expenditure on education & IIF6 & $0.580($ Omitted $)$ \\
\hline \multicolumn{2}{|c|}{ Human factors } & \multicolumn{2}{|l|}{ IHF } \\
\hline & PISA scales in reading, math, \& science & IHF1 & 0.881 \\
\hline & Graduates in science \& engineering & IHF2 & 0.107 (Omitted) \\
\hline & Tertiary level inbound mobility & IHF3 & 0.536 (Omitted) \\
\hline & Researchers, full time equivalent/million people & IHF4 & 0.930 \\
\hline & Employment in knowledge-intensive services & IHF5 & 0.862 \\
\hline & Research talent in business enterprise & IHF6 & 0.816 \\
\hline \multicolumn{2}{|c|}{ Linkage factors } & \multicolumn{2}{|l|}{ ILF } \\
\hline & GERD performed by business enterprise & ILF1 & 0.917 \\
\hline & GERD financed by business enterprise & ILF2 & 0.910 \\
\hline & University-industry research collaboration & ILF3 & $0.920(\text { Omitted })^{*}$ \\
\hline & State of cluster development & ILF4 & 0.918 (Omitted)* \\
\hline & Joint venture/strategic alliance deals & ILF5 & 0.506 (Omitted) \\
\hline \multicolumn{2}{|c|}{ Framework factors } & \multicolumn{2}{|l|}{ IFF } \\
\hline & ICT access & IFF1 & 0.906 \\
\hline & ICT use & IFF2 & $0.951(\text { Omitted })^{*}$ \\
\hline & Electricity output, $\mathrm{kWh} / \mathrm{mn}$ pop. & IFF3 & 0.525 (Omitted) \\
\hline & Logistics performance & IFF4 & 0.916 \\
\hline & Gross capital formation & IFF5 & 0.055 (Omitted) \\
\hline & Environmental performance & IFF6 & 0.897 \\
\hline & The rule of law & IFF7 & $0.953(\text { Omitted })^{*}$ \\
\hline \multicolumn{2}{|c|}{ Output intangible indicators } & \multicolumn{2}{|l|}{ OII } \\
\hline & Patent applications by origin & OII1 & 0.923 \\
\hline & PCT international applications by origin & OII2 & 0.941 \\
\hline & Scientific and technical publications & OII3 & 0.478 (Omitted) \\
\hline & Trademark application class count by origin & OII4 & 0.357 (Omitted) \\
\hline & Industrial designs by origin & OII5 & 0.533 (Omitted) \\
\hline & ICTs and business model creation & OII6 & 0.898 \\
\hline \multicolumn{2}{|c|}{ Output tangible indicators } & \multicolumn{2}{|l|}{ OTI } \\
\hline & Cultural and creative services exports & OTI1 & 0.668 (Omitted) \\
\hline & Creative goods exports & OTI2 & 0.446 (Omitted) \\
\hline & The growth rate of GDP per person engaged & OTI3 & 0.517 (Omitted) \\
\hline & High-tech and medium high-tech output & OTI4 & 0.468 (Omitted) \\
\hline & New business density & OTI5 & 0.484 (Omitted) \\
\hline
\end{tabular}

* The indicators that do not meet collinearity criteria

Estimation Results and Statistical Verification of the Model

Figure 2 shows the PLS-SEM estimation results obtained in the SmartPLS software (Ringle et al. 2015). The results are interpreted in section "Results and Discussion". 


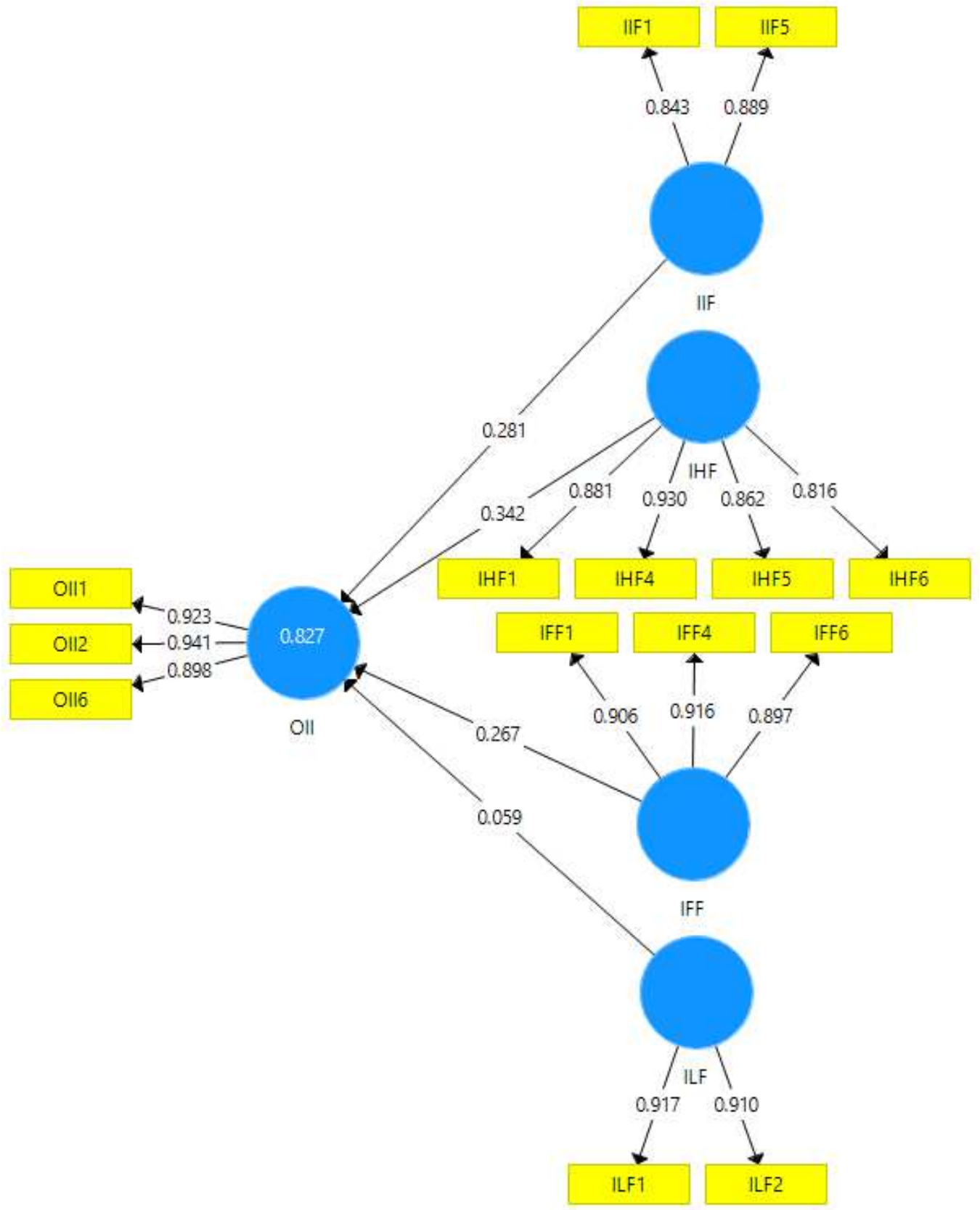

Fig. 2. Results of estimation of PLS-SEM $2015-2018$ model 
Table 4 contains the results of the estimation of the outer sub model.

Table 4 Assessing the results of outer models

\begin{tabular}{llcccc}
\hline $\begin{array}{l}\text { Latent } \\
\text { variables }\end{array}$ & Indicators & rho_A & $\begin{array}{c}\text { Average } \\
\text { Variance } \\
\text { Extracted } \\
\text { (AVE) }\end{array}$ & $\begin{array}{c}\text { Composite } \\
\text { Reliability }\end{array}$ & $\begin{array}{c}\text { Cronbach's } \\
\text { Alpha }\end{array}$ \\
\hline IIF & IIF1 & 0.681 & 0.750 & 0.857 & 0.669 \\
\hline IHF & IIF5 & & & 0.928 & 0.896 \\
& IHF1 & 0.902 & 0.763 & & \\
& IHF4 & & & 0.910 & \\
\hline ILF & IHF5 & & & & \\
\hline IFF & ILF1 & 0.803 & 0.834 & & \\
& ILF2 & & & & \\
\hline OII & IFF1 & 0.895 & 0.821 & & \\
& IFF4 & & & & \\
& IFF6 & & & & \\
& OII1 & 0.916 & 0.848 & & \\
\hline
\end{tabular}

* Average Variance Extracted (AVE)

Individual indicator reliability values significantly larger than the lowest acceptable level of 0.4 can be observed (Hulland 1999).

Cronbach's alpha and composite reliability are shown to be larger than 0.6 , which means that high levels of internal consistency reliability have been demonstrated among the latent variables.

In order to confirm convergent validity, the average variance extracted (AVE) is evaluated for each latent variable. Table 4 also shows that the AVE values are greater than the acceptable threshold of 0.5 , which confirms convergent validity.

As suggested by Fornell and Larcker (1981), if this value exceeds other latent variables' correlation values, we can use the square root of AVE in each latent variable to establish discriminant validity.

Table 5 Fornell-Larcker criterion analysis for checking discriminant validity

\begin{tabular}{llllll}
\hline & IFF & IHF & IIF & ILF & OII \\
\hline IFF & 0.915 & & & & \\
IHF & 0.920 & 0.863 & & & \\
IIF & 0.940 & 0.942 & 0.900 & & \\
ILF & 0.863 & 0.929 & 0.879 & 0.879 & 0.919 \\
OII & 0.886 & 0.893 & 0.904 & 0.905 & \\
\hline
\end{tabular}

The latent variable OII's AVE is found to be 0.944 (from Table 4) hence its square root becomes 0.920 (Table 5). The result indicates that discriminant validity is well established. 
Using a two-tailed t-test with a significance level of 5\%, the path coefficient will be significant if the T-statistics is larger than 1.96. As presented in Table 6 all path coefficients in the inner model are statistically significant.

Table 6 Assessing the results of inner models

\begin{tabular}{lccccc}
\hline & Path coefficients & $\begin{array}{c}\text { Standard } \\
\text { Deviation } \\
(\text { STDEV })\end{array}$ & $\begin{array}{c}\text { T-Statistics } \\
(|\mathrm{O} / \mathrm{STDEV}|)\end{array}$ & P Values & $\mathrm{R}^{2}$ \\
\cline { 2 - 6 } $\mathrm{IFF} \rightarrow$ OII & 0.191 & 0.256 & 0.749 & 0.454 & \\
$\mathrm{IHF} \rightarrow$ OII & -0.156 & 0.238 & 0.657 & 0.512 & 0.827 \\
$\mathrm{IIF} \rightarrow$ OII & 0.407 & 0.224 & 1.818 & 0.070 & \\
$\mathrm{ILF} \rightarrow$ OII & 0.488 & 0.163 & 2.992 & 0.003 & \\
\hline
\end{tabular}

The values of the Stone-Geisser test statistic, which verifies the model in terms of its predictive usefulness (see Table 7), are positive, which proves the model's high predictive quality.

Table 7 Stone-Geisser test $Q^{2}$ values

\begin{tabular}{lc}
\hline Indicator & $2015-2018$ \\
\hline OII1 & 0.516 \\
OII2 & 0.482 \\
OII6 & 0.798 \\
General & 0.827 \\
\hline
\end{tabular}

Source: authors' own work.

Both the measurement models and the structural models were positively assessed, therefore, in the next stage of modeling, the results can be interpreted.

\section{Results and Discussion}

Figures $3(\mathrm{a}-\mathrm{e})$ present the ordering of the indicators of each of the latent variables in terms of values of outer loadings, i.e., in terms of the strength of the relationship between the values of the latent variable and the values of the indicators.

The following interpretation of the $\pi i j$ outer loading is assumed:

$-|\pi \mathrm{ij}|<0.2-$ no correlation,

$-0.2 \leq|\pi \mathrm{ij}|<0.4$-weak correlation,

$-0.4 \leq|\pi \mathrm{ij}|<0.7$-moderate correlation,

$-0.7 \leq|\pi \mathrm{ij}|<0.9$ - strong correlation,

$-|\pi \mathrm{i}| \geq 0.9$ — very strong correlation. 


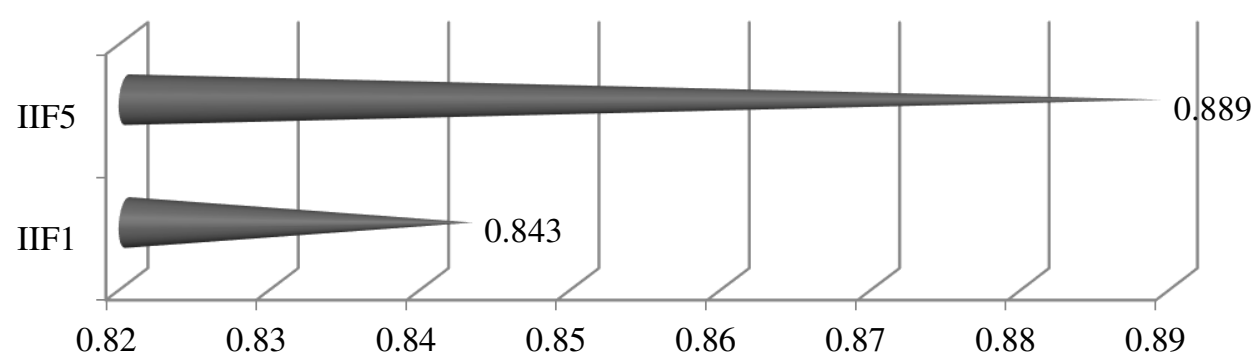

Fig. 3a. Estimations of factor loadings of IIF latent variable

The latent variable IIF is very strongly reflected by two indicators: "Gross expenditure on R\&D" (IIF5) and "Political and operational stability" (IIF1).

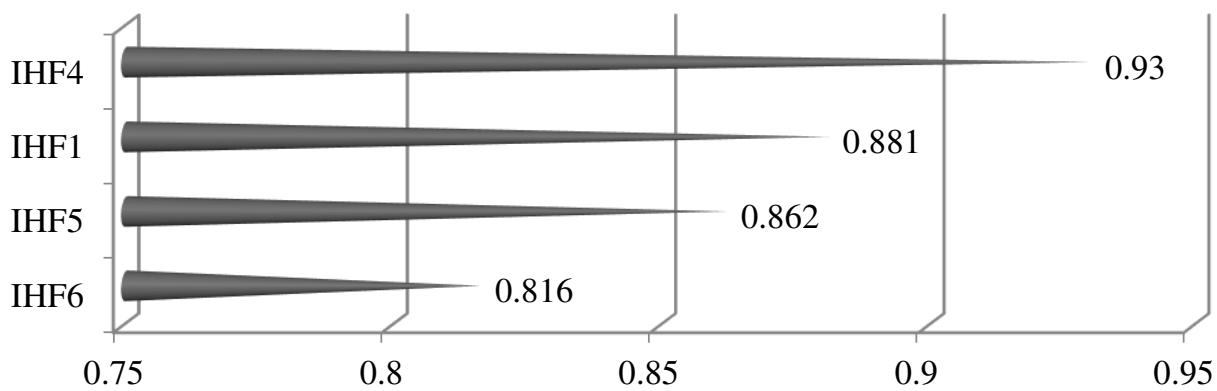

Fig. 3b. Estimations of factor loadings of IHF latent variable

The latent variable IHF is very strongly reflected by one indicator-"Researchers in R\&D (per million people)" (IHF4) — and strongly reflected by three indicators: "Employment in knowledgeintensive services" (IHF5); "PISA scales in reading, math, and science" (IHF1); and "Research talent in business enterprise" (IHF6).

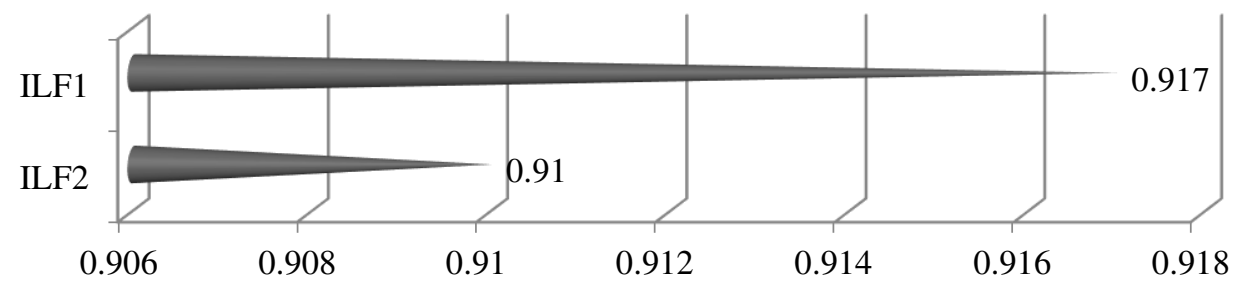

Fig. 3c. Estimations of factor loadings of ILF latent variable

Two indicators very strongly reflect the latent variable ILF: "GERD performed by business enterprise" (ILF1), and "GERD financed by business enterprise" (ILF2). 


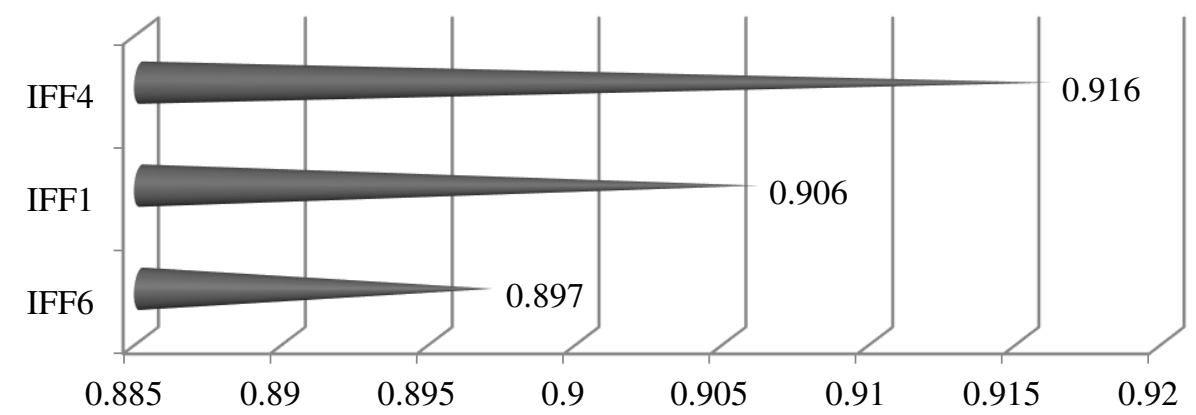

Fig. 3d. Estimations of factor loadings of IFF latent variable

The latent variable IFF is very strongly reflected by two indicators: "Logistics performance" (IFF4) and "ICT access" (IFF1). Also, the latent variable ILF is strongly reflected by one indicator, "Environmental performance" (IFF6).

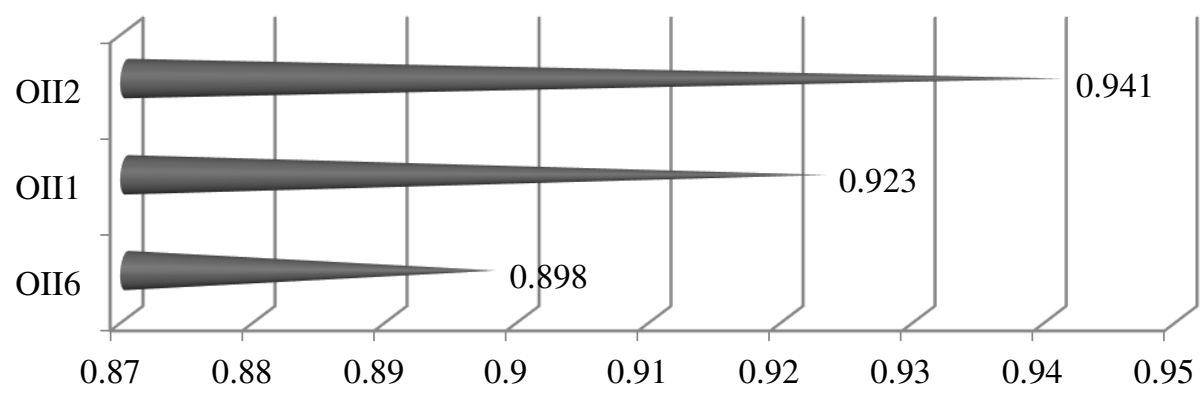

Fig. 3e. Estimations of factor loadings of OII latent variable

The latent variable OII is very strongly reflected by two indicators: "PCT international applications by origin" (OII2) and "Patent applications by origin" (OII1). Moreover, the latent variable OII is strongly reflected by one indicator- "ICTs and business model creation" (OII6). The estimation of the internal model parameters indicates a significant positive correlation between UIC predictors and the level of UIC performance in the studied group of 33 European countries in the period 2015-2018. This means that those countries that reported a higher level of development of input factors also had a better UIC performance in the observed period.

$$
\mathrm{OIIt}=0.488 * \mathrm{ILF}_{2015-2018}+3.76956
$$

Aside from investigating latent variables correlations, this way of modelling also helps estimate these variables' values (weighted sums of indicators). For that reason, a synthetic measurement, with which we can obtain a linear ordering of the studied objects, is calculated for each of the model's latent variables.

\footnotetext{
${ }^{6}$ Parameter $\alpha_{0}$ was estimated in the PLS program (Rogowski 1990).
} 
Based on estimated values of the input and output variables, rankings of the studied countries have been compiled: a ranking of input and output variables. The results are shown in Table 8 .

Table 8 Rankings of UIC input and output indicators over the period of three years (2015-2018)

\begin{tabular}{|c|c|c|c|c|c|}
\hline Country & IFF & IHF & IIF & ILF & OII \\
\hline Albania & 32 & 33 & 32 & 33 & 32 \\
\hline Austria & 8 & 7 & 5 & 3 & 8 \\
\hline Belgium & 11 & 5 & 9 & 4 & 12 \\
\hline Bosnia and Herzegovina & 33 & 32 & 33 & 32 & 33 \\
\hline Bulgaria & 27 & 25 & 28 & 23 & 26 \\
\hline Croatia & 26 & 24 & 25 & 26 & 28 \\
\hline Cyprus & 19 & 27 & 21 & 25 & 25 \\
\hline Czech Republic & 15 & 15 & 13 & 16 & 19 \\
\hline Denmark & 2 & 1 & 2 & 6 & 5 \\
\hline Estonia & 14 & 13 & 12 & 17 & 15 \\
\hline Finland & 7 & 2 & 1 & 2 & 1 \\
\hline France & 6 & 8 & 14 & 9 & 7 \\
\hline Germany & 5 & 4 & 3 & 1 & 2 \\
\hline Greece & 24 & 26 & 29 & 31 & 31 \\
\hline Hungary & 25 & 16 & 23 & 18 & 22 \\
\hline Ireland & 10 & 9 & 7 & 8 & 14 \\
\hline Italy & 17 & 20 & 24 & 11 & 16 \\
\hline Latvia & 22 & 22 & 22 & 30 & 24 \\
\hline Lithuania & 18 & 19 & 15 & 24 & 21 \\
\hline Luxemburg & 1 & 6 & 6 & 12 & 3 \\
\hline Malta & 12 & 17 & 16 & 15 & 10 \\
\hline Montenegro & 31 & 29 & 31 & 28 & 29 \\
\hline The Netherlands & 4 & 3 & 4 & 5 & 4 \\
\hline North Macedonia & 30 & 30 & 27 & 22 & 20 \\
\hline Poland & 23 & 18 & 19 & 21 & 18 \\
\hline Portugal & 21 & 23 & 20 & 20 & 17 \\
\hline Romania & 28 & 31 & 30 & 27 & 30 \\
\hline Serbia & 29 & 28 & 26 & 29 & 27 \\
\hline Slovakia & 20 & 21 & 18 & 19 & 23 \\
\hline Slovenia & 16 & 12 & 17 & 14 & 13 \\
\hline Spain & 9 & 14 & 11 & 13 & 11 \\
\hline Sweden & 13 & 11 & 10 & 10 & 6 \\
\hline United Kingdom & 3 & 10 & 8 & 7 & 9 \\
\hline
\end{tabular}

The countries are also divided into typological groups, according to similar volumes of UIC inputs and outputs. The results of the grouping are presented in Figs. 4 a-e. The boundaries between the groups have been established based on the arithmetic means and standard deviations of the synthetic measure $z_{\mathrm{i}}$ (equal to 0 and 1, respectively, for each of the latent variables). The groups are as follows:

- Group I (very high level of latent variable): $z_{i} \geq 1$,

- Group II (high level of latent variable): $0<z_{i} \leq 1$,

- Group III (medium and low level of latent variable): $-1<z_{i} \leq 0$,

- Group IV (very low level of latent variable): $z_{i} \leq-1$. 


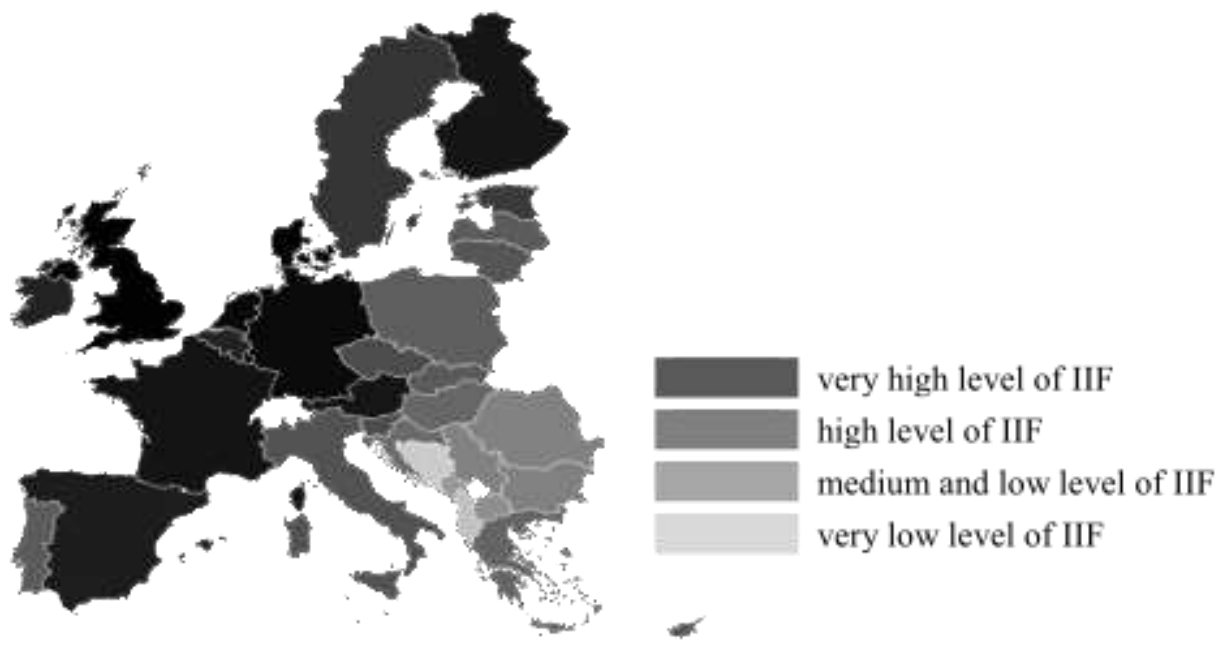

Fig. 4a. Division of EU countries into typological groups according to institutional factors

A very high level of institutional factor development' was observed in the following six countries: Finland, Denmark, Germany, the Netherlands, Austria, and Luxemburg. The group of the countries with a high level of institutional factors development comprised eleven countries: Ireland, United Kingdom, Belgium, Sweden, Spain, Estonia, Czech Republic, France, Lithuania, Malta, and Slovenia. Nine countries were qualified for the group of economies with a medium level of institutional factors development: Slovakia, Poland, Portugal, Cyprus, Latvia, Hungary, Italy, Croatia, and Serbia. Six countries were characterized by low levels of institutional factors development: North Macedonia, Bulgaria, Greece, Romania, Montenegro, and Albania. Finally, Bosnia and Herzegovina is in the bottom place as the country with the lowest level of institutional factors development.

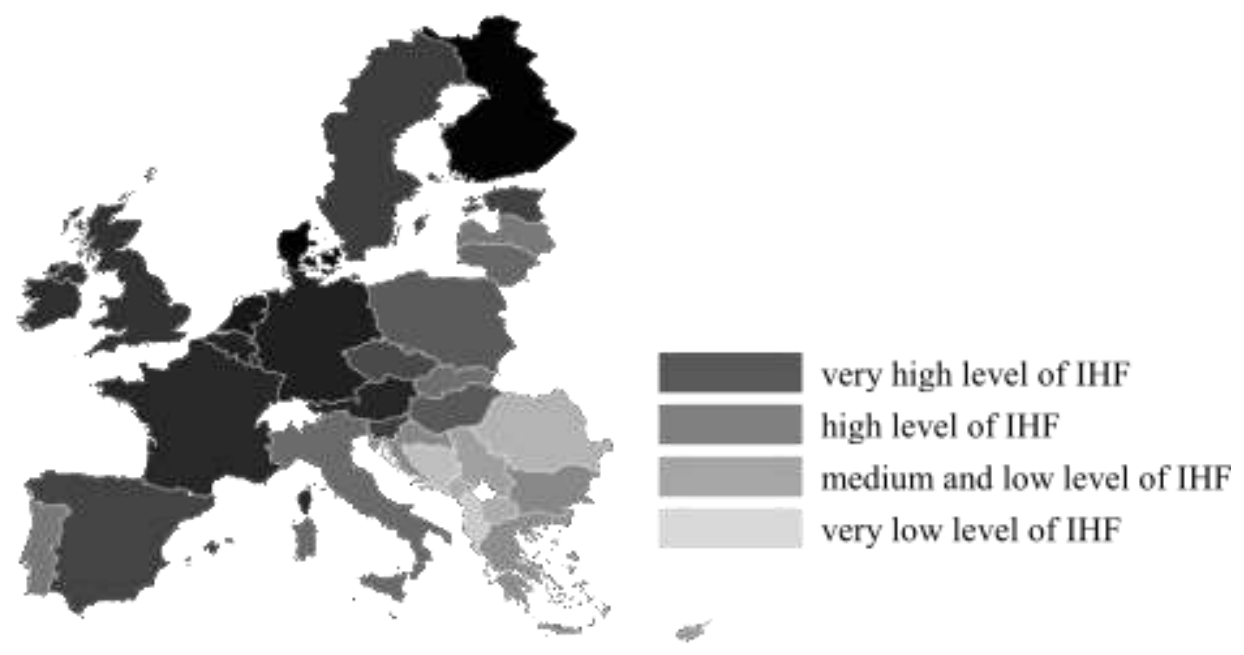

Fig. 4b. Division of EU countries into typological groups according to human factors

When one considers the human factors, the classification looks somewhat different. Here, the top ranks are occupied by EU member states based on highly developed human capital, focusing on functional literacy, knowledge, and the R\&D sector (Denmark, Finland, the Netherlands, 
Germany, Belgium, Luxemburg, and Austria). The group with a high level of human capital development comprised 11 countries: France, Ireland, United Kingdom, Sweden, Slovenia, Estonia, Spain, Czech Republic, Hungary, Malta, and Poland. Eight countries were qualified for the group of economies with a medium level of human capital development: Lithuania, Italy, Slovakia, Latvia, Portugal, Croatia, Bulgaria, and Greece.

Countries with weak indicators of functional literacy and of knowledge, and a small percentage of spending on R\&D sectors (Cyprus, Serbia, Montenegro, North Macedonia, Romania, Bosnia and Herzegovina, Albania) are ranked at the bottom.

According to institutional factors, the ranking of countries demonstrates a dominance of North and Western European economies and those "catch-up" economies from Central Europe. Economies of Southeastern Europe occupy the lower ranks.

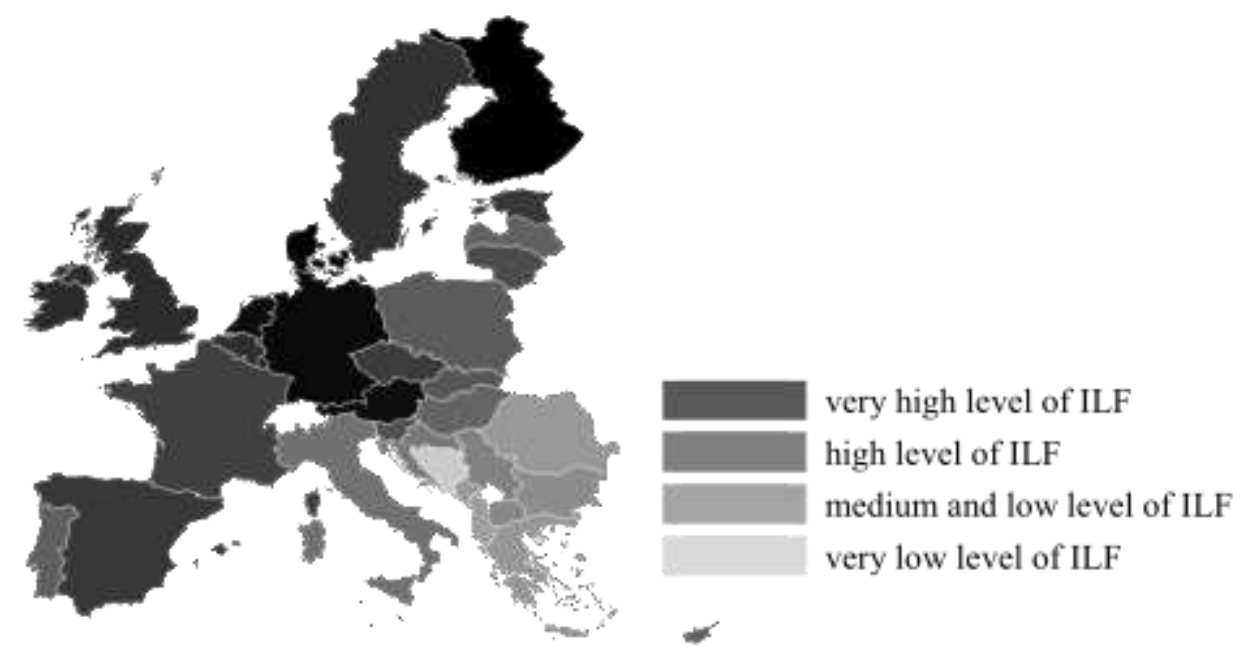

Fig. 4c. Division of EU countries into typological groups according to linkage factors

A very high level of developed linkage factors was observed in the following six countries: Finland, Denmark, Germany, the Netherlands, Austria, and Luxemburg. The group with a high level of developed linkage factors comprised 11 countries: Ireland, United Kingdom, Belgium, Sweden, Spain, Estonia, Czech Republic, France, Lithuania, Malta, and Slovenia. Nine countries qualified for the group of economies with a medium level of developed linkage factors: Slovakia, Poland, Portugal, Cyprus, Latvia, Hungary, Italy, Croatia, and Serbia. Six countries were characterized by low levels of developed linkage factors: North Macedonia, Bulgaria, Greece, Romania, Montenegro, and Albania. Bosnia and Herzegovina was characterized as the country with very low levels of developed linkage factors. 


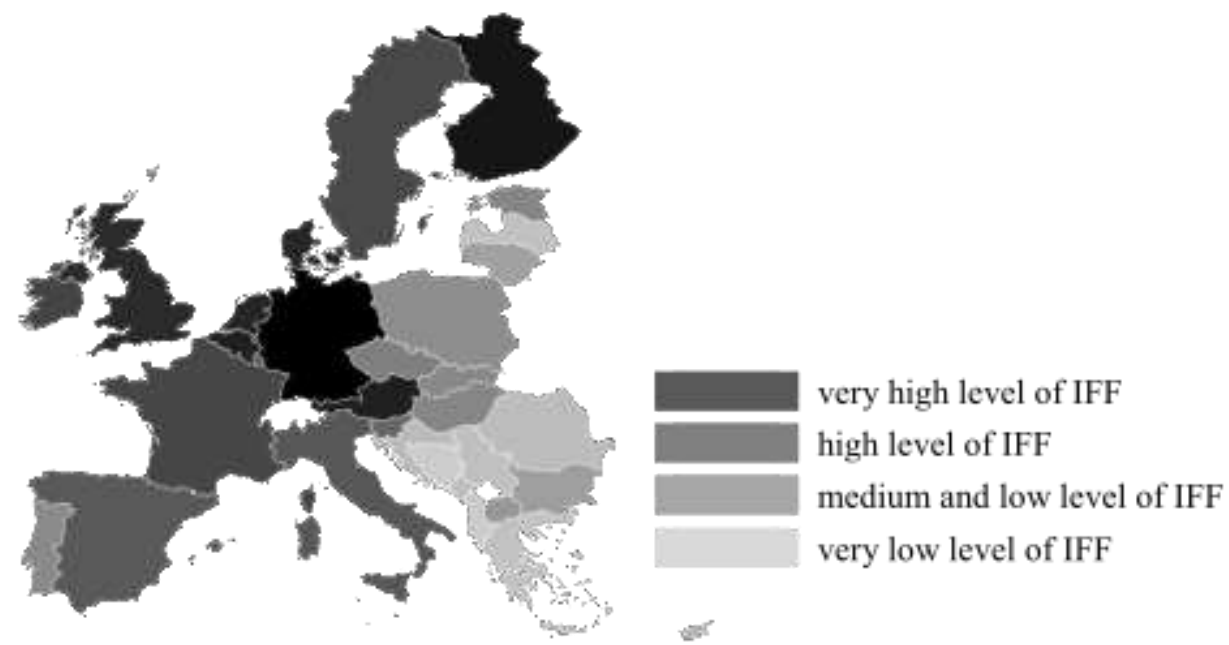

Fig. 4d. Division of EU countries into typological groups according to framework factors

A very high level of developed framework factors was observed in the following eight countries: Luxemburg, Denmark, United Kingdom, the Netherlands, Germany, France, Finland, and Austria. The group with a high level of developed framework factors comprised six countries: Spain, Ireland, Belgium, Malta, Sweden, and Estonia. Thirteen countries were qualified for the group of economies with a medium level of developed framework factors: Czech Republic, Slovenia, Italy, Lithuania, Cyprus, Slovakia, Portugal, Latvia, Poland, Greece, Hungary, Croatia, and Bulgaria. Four countries were characterized by low levels of developed framework factors: Romania, Serbia, North Macedonia, and Montenegro. Finally, two Balkan countries were characterized by very low levels of developed framework factors: Albania and Bosnia and Herzegovina.

According to framework factors, the countries' ranking demonstrates a dominance of North and Western European economies and those "catch-up" economies from Central Europe. Economies of Southeastern Europe occupy the lower ranks.

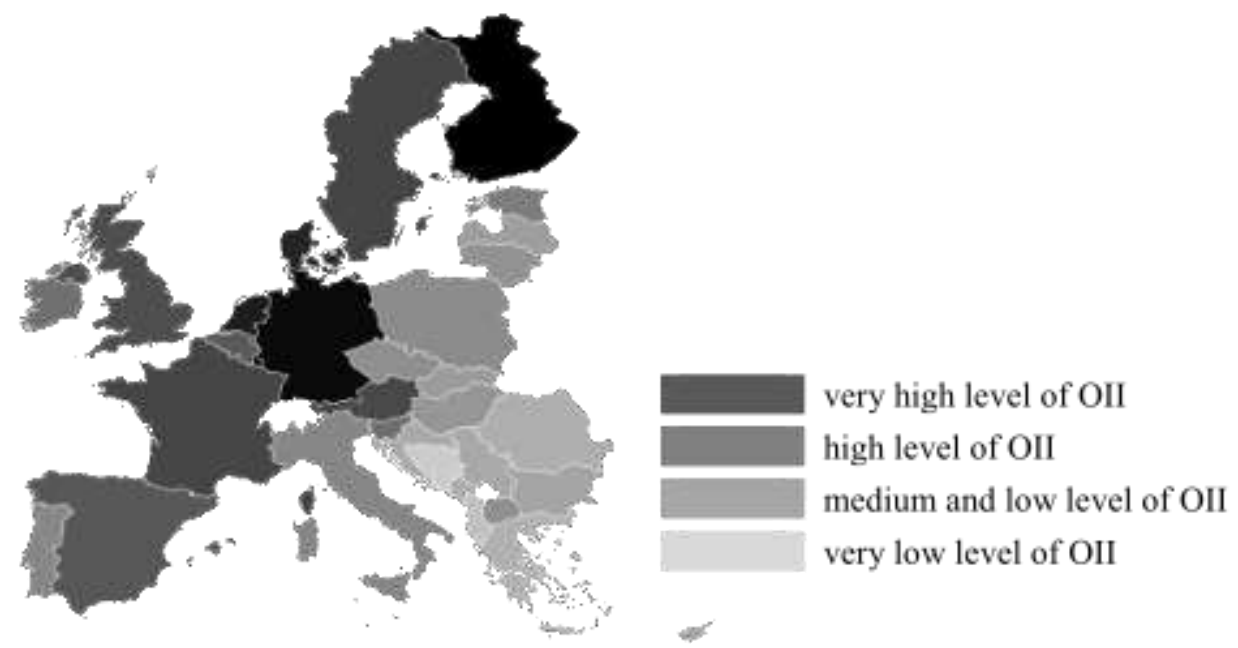

Fig. 4e. Division of EU countries into typological groups according to intangible output indicators 
As presented in the analysis of intangible output indicators, the top ranks are occupied by five EU member states based on highly developed human capital, focusing on functional literacy, innovation, ICT use, and the R\&D sector (Finland, Germany, Luxemburg, the Netherlands and Denmark.). The group with a high level of intangible output indicators comprised nine countries: Sweden, France, Austria, United Kingdom, Malta, Spain, Belgium, Slovenia, and Ireland. Fifteen countries qualified for the group of economies with medium and low levels of intangible output indicators: Estonia, Italy, Portugal, Poland, Czech Republic, North Macedonia, Lithuania, Hungary, Slovakia, Latvia, Cyprus, Bulgaria, Serbia, Croatia, and Montenegro. Countries with weak indicators of patent applications by origin, PCT international applications by origin, and ICTs and business model creation (Romania, Greece, Albania and Bosnia and Herzegovina) were ranked at the bottom.

Within the EU-28, most countries treat UIC as a vital source of increasing the performance of companies. Nevertheless, the Balkan countries still lack cooperation between the universities and companies.

\section{Conclusions}

This article presents empirical studies' results of the relationship between UIC predictors and performances in selected European countries. The research involved developing a PLS-SEM model, measurement of the latent variables based on sets of observable variables, and the estimation and verification of the PLS-SME model. The modeling outcomes reveal a significant favorable influence of impact factors on the UIC performance in the analyzed European countries. Based on the literature review, the authors identified four main groups of factors that impact UIC performance. Firstly, there are institutional factors, which refer to the business environment and expenditures on R\&D; secondly, there are human factors, which refer to functional literacy and research; thirdly, there is a linkage factor, which refers to relationships between universities and firms; and fourthly, there are framework factors, which refer to the business infrastructure. Finally, the authors defined the "output factors" that present the level of UIC in a specific country.

On average, predictors of successful UIC are led by EU-15 member states. A very high-level input indicator was observed in the following seven countries: Denmark, Finland, Germany, the Netherlands, Austria, Luxemburg, and the United Kingdom. The group with a high level of developed input factors comprised nine countries: Belgium, Ireland, France, Sweden, Spain, Estonia, Slovenia, Czech Republic, and Malta. Eleven countries qualified for the group of economies with a medium level of developed input factors: Italy, Poland, Lithuania, Slovakia, Hungary, Portugal, Latvia, Cyprus, Croatia, Bulgaria, and Greece. Six Balkan countries are ranked bottom in Europe, and these are countries with a low level of institutional factors development: North Macedonia, Serbia, Romania, Montenegro, Albania, and Bosnia and Herzegovina.

To improve the economic situation in the region, the Balkan countries should, in the long term, revise their education systems and invest more money in knowledge, networking, and R\&D in general. Based on both public and private initiatives, this investment will have a long-term positive impact on companies' productivity, as well as their profit. Furthermore, they should follow successful examples from the EU member states and launch specialized programs for supporting innovation in the short term. The authors suggest Austria and Slovenia as the best model countries for the Balkan region since these two countries have been the best example for the Balkan economies in many fields throughout history. Moreover, universities must be more focused on the companies' real needs in the future if they want to justify their role in society. 
This article provides new knowledge on how different factors accelerate UIC in Europe. To the best of the authors' knowledge, it is the first research to investigate links between institutional factors, human capital, linkage factors, and framework factors on the one side, and output factors

of UIC on the other by using the PLS-SEM method. Based on the described indicators, the authors improved a UIC model driven by investments in linkage factors.

\section{List of abbreviations}

AVE - Average variance extracted

CB - Covariance-based

CB-SEM - Covariance-based structural equation modeling

GDP - Gross domestic product

GERD - Gross domestic expenditure on R\&D

GII - Global Innovation Index

HTMT - Heterotrait-monotrait ratio

PCT - Patent Cooperation Treaty

PLS - Partial least square method

PLS-SEM - Partial least squares structural equation modeling

R\&D - Research and development

SEM - Structural equation modeling method

STDEV - Standard Deviation

UIC - Between university-industry collaboration

VIF - Variance Inflation Factor

WIPO - World Intellectual Property Organization

\section{Declarations}

Availability of data and materials: Public data, provided by WIPO, 2015-2018:

https://www.wipo.int/edocs/pubdocs/en/wipo_pub_gii_2020.pdf.

Competing interests: Not applicable

Funding: The article is created within the programme group P6-0372 and supported by

Slovenian Research Agency - 5442-1/2018/89.

\section{Authors' contributions:}

Bojan Ćudić investigated links between institutional factors, human capital, linkage factors, and framework factors on the one side, and output factors of UIC on the other by using the PLS-SEM method.

Peter Alešnik provided literature review about the factors impacting university-industry collaboration.

David Hazemali provided dataset, and worked on technical issues in the paper (copy editing, creation of tables and figures, etc.).

Acknowledgements: Many thanks to Dr. Iwona Skrodzka for support in creating the PLS-SME method that enabled us to conduct this research. 


\section{References}

Aiello, F. \& Cardamone, P. \& Pupo, V. (2019). New evidence on the firm-university linkages in Europe. The role of meritocratic management practices. Working Papers 201905, Università della Calabria, Dipartimento di Economia, Statistica e Finanza "Giovanni Anania" - DESF.

Al-Agtash, S. \& Al-Fahoum, F. (2008). An innovative model for university-industry partnership. International Journal of Innovation and Learning, Inderscience Enterprises Ltd., 5(5), 512-532.

Albats, E. \& Bogers, M. \& Podmetina, D. (2020). Companies' human capital for university partnerships: a micro-foundational perspective. Technological Forecasting and Social Change. Elsevier 157(C). https://doi.org/10.1016/j.techfore.2020.120085.

Ankrah, S. \& AL-Tabbaa, O. (2015). Universities-industry collaboration: a systematic review. Scandinavian Journal of Management. https://doi.org/10.1016/j.scaman.2015.02.003.

Arvanitis, S. \& Kubli, U. \& Woerter, M. (2008). University-industry knowledge and technology transfer in Switzerland: what university scientists think about cooperation with private enterprises. Research Policy. 37(10), 1865-1883. https://doi.org/10.1016/j.respol.2008.07.005.

Attia, A.M. (2015). National innovation systems in developing countries: barriers to universityindustry collaboration in Egypt. International Journal of Technology Management \& Sustainable Development. 14(2), 113-124. https://doi.org/10.1386/tmsd.14.2.113_1.

Banal-Estañol, A. et al. (2011). Research output from university-industry collaborative projects. Working Papers 2011/23, Institut d'Economia de Barcelona (IEB).

Barnes, T. \& Pashby, I. \& Gibbons, A. (2002). Effective university-industry interaction: a multi-case evaluation of collaborative R\&D projects. European Management Journal. 20(3), 272-285. https://doi.org/10.1016/s0263-2373(02)00044-0.

Betz, F. \& Khalil, F. \& Hosni, Y. (2010). Creating and managing a technology economy (management of technology), World Scientific Publishing Company, Singapore.

Boardman, C. \& Bozeman, B. (2015). Academic faculty as intellectual property in universityindustry research alliances. Economics of Innovation and New Technology. 24(5), 403-420. https://doi.org/10.1080/10438599.2014.988499.

Bodas Freitas, I.M. \& Geuna, A. \& Rossi, F. (2013). Finding the right partners: institutional and personal modes of governance of university-industry interactions. Research Policy. 42(1), 50-62. https://doi.org/10.1016/j.respol.2012.06.007.

Bstieler, L. \& Hemmert, M. \& Barczak, G. (2017). The changing bases of mutual trust formation in inter-organisational relationships: a dyadic study of university-industry research collaborations.

Journal of Business Research. 74, 47-54. https://doi.org/10.1016/j.jbusres.2017.01.006.

Chin, W.W. \& Marcolin, B.L. \& Newsted, P.R. (1996). A partial least squares latent variable modelling approach for measuring interaction effects: results from a Monte Carlo simulation study and voice mail emotion/adoption study. Paper presented at the 17th International Conference on Information Systems, Cleveland. https://doi.org/10.1287/isre.14.2.189.16018.

Collier, A. \& Gray, B.J. \& Ahn, M.J. (2011). Enablers and barriers to university and high technology SME partnerships. Small Enterprise Research. 18(1), 2-18. https://doi.org/10.5172/ser.18.1.2.

Cornell University, INSEAD, and WIPO (2010-2020) The Global Innovation Index 2020: Who will finance innovation? Ithaca, Fontainebleau, and Geneva.

D’Costa, A.P. (2006). Exports, university-industry linkages, and innovation challenges in Bangalore, India. Policy Research Working Paper Series 3887, The World Bank.

de Medeiros Rocha, M. \& Brito Alves Lima, G. \& Lameira, V.d.J. \& Gonçalves Quelhas, O.L. (2012). Innovation as a critical success factor: an exploratory study about the partnership among university 
with the pharmaceutical industry in Brazil. Journal of Technology Management \& Innovation. 7(3), 148-160. http://dx.doi.org/10.4067/S0718-27242012000300013.

Draghici, A. \& Baba, C.F. \& Draghici, G. \& Ivascu, L.V. (2016). The development of an evaluation model for universities and industry collaboration in open innovation. Proceedings of the MakeLearn and TIIM Joint International Conference.

Esposito Vinzi, V. \& Chin, W.W. \& Henseler, K. \& Wand, H. (eds) (2010). Handbook of partial least squares: concepts, methods and applications, Springer, Berlin. ISBN: 978-3-540-32827-8.

Fernandes, C.I. \& Ferreira, J.J.M. (2013). Knowledge spillovers: cooperation between universities and KIBS. R\&D Management. 43(5), 461-472. https://doi.org/10.1111/radm.12024.

Ferru, M. (2010). Formation process and geography of science-industry partnerships: the case of the University of Poitiers. Industry and Innovation. 17(6), 531-549. https://doi.org/10.1080/13662716.2010.509998.

Flores, M. \& Boër, C. \& Huber, C. \& Plüss, A. \& Schoch, R. \& Pouly, M. (2009). Universities as key enablers to develop new collaborative environments for innovation: successful experiences from Switzerland and India. International Journal of Production Research. 47(17), 4935-4953. https://doi.org/10.1080/00207540902847454.

Fornell, C. \& Larcker, D.F. (1981). Evaluating structural equation models with unobservable variables and measurement error. Journal of Marketing Research. 18(1), 39-50. https://doi.org/10.1177/002224378101800104.

George, G. \& Zahra, S.A. \& Wood, D.R. (2002). The effects of business-university alliances on innovative output and financial performance: a study of publicly traded biotechnology companies. Journal of Business Venturing. 17(6), 577-609. https://doi.org/10.1016/S0883-9026(01)00069-6.

Goel, R. \& Göktepe-Hulten, D. \& Grimpe, C. (2017). Who instigates university-industry collaborations? University scientists versus firm employees. Small Business Economics. 48, 503524. https://doi.org/10.1007/s11187-016-9795-9.

Guan, J.C. \& Yam, R.C.M. \& Mok, C.K. (2005). Collaboration between industry and research institutes/universities on industrial innovation in Beijing, China. Technology Analysis \& Strategic Management. 17(3), 339-353. https://doi.org/10.1080/09537320500211466.

Hadjimanolis, A. (2006). A case study of SME-university research collaboration in the context of a small peripheral country (Cyprus). International Journal of Innovation Management. 10(1), 6588. https://doi.org/10.1142/S1363919606001405.

Hair, J.F. \& Hult, G.T.M. \& Ringle, C.M. \& Sarstedt, M. (2017). A primer on partial least squares structural equation modeling PLS-SEM, Sage, Thousand Oaks, CA.

Hair, J.F. \& Risher, J.J. \& Sarstedt, M. \& Ringle, C.M. (2019). When to use and how to report the results of PLS-SEM. European Business Review. 31(1), 2-24. https://doi.org/10.1108/EBR-112018-0203.

Hemmert, M., \& Bstieler, L., \& Okamuro, H. (2014). Bridging the cultural divide: trust formation in university-industry research collaborations in the US, Japan, and South Korea. Technovation, 34(10), 605-616. https://doi.org/10.1016/j.technovation.2014.04.006.

Henderson, J., \& McAdam, R., \& Leonard, D. (2006). Reflecting on a TQM-based university/industry partnership: contributions to research methodology and organisational learning. Management Decision 44(10), 1422-1440. https://doi.org/10.1108/00251740610715731.

Henseler, J., \& Dijkstra, T.K. (2015). ADANCO 2.0. Composite Modeling GmbH \& Co. KG.

Henseler, J., \& Ringle, C.M., \& Sarstedt, M. (2012). Using partial least squares path modeling in international advertising research: basic concepts and recent issues. In: Okazaki WS (ed) Handbook of research in international advertising, Edward Elgar, 252-276. 
Hillebrand, B., \& Biemans, W.G. (2003). The relationship between internal and external cooperation. Journal of Business Research 56(9), 735-743. https://doi.org/10.1016/s0148-2963(01)00258-2.

Hong, J., \& Heikkinen, J., \& Blomqvist, K. (2010). Culture and knowledge co-creation in R\&D collaboration between MNCs and Chinese universities. Knowledge and Process Management, 17(2), 62-73. https://doi.org/10.1002/kpm.342.

Hulland, J. (1999). Use of Partial Least Squares (PLS) in Strategic Management Research: A Review of Four Recent Studies. Strategic Management Journal. 20(2), 195-204. https://doi.org/10.1002/(SICI)1097-0266(199902)20:2<195::AID-SMJ13>3.0.CO;2-7.

Hwang, I. (2020). The effect of collaborative innovation on ICT-based technological convergence: a patent-based analysis. PLoS ONE, Public Library of Science, 15(2), 1-20. https://doi.org/10.1371/journal.pone.0228616.

Jöreskog, K.G. \& Wold, H. (1982). The ML and PLS techniques for modeling with latent variables: historical and comparative aspects. In: Jöreskog KG, Wold H (eds) Systems under indirect observations: causality, structure, prediction, Vol. 1, North-Holland, Amsterdam, 263-270.

Kock, N. (2020). WarpPLS user manual: Version 7.0. TX: ScriptWarp Systems.

Koschatzky, K. \& Stahlecker, T. (2010). The changing role of universities in the German research system: engagement in regional networks, clusters and beyond. Working Papers Firms and Region. R2/2010, Fraunhofer Institute for Systems and Innovation Research (ISI).

Kozlinska, I. (2012). Obstacles to university-industry cooperation in the domain of entrepreneurship. Journal of Business Management. 6(1), 153-160.

Lai, I. \& Lu, T-W. (2016). How to improve the university-industry collaboration in Taiwan's animation industry? Academic vs. industrial perspectives. Technology Analysis \& Strategic Management. 28(6), 717-732. https://doi.org/10.1080/09537325.2016.1141404.

Lee, K-J. (2011). From interpersonal networks to inter-organisational alliances for universityindustry collaborations in Japan: the case of the Tokyo Institute of Technology. $R \& D$ Management. 41(2), 190-201. https://doi.org/10.1111/j.1467-9310.2011.00633.x.

Marotta, D. \& Mark, M. \& Blom, A. \& Thorn, K (2007). Human capital and university-industry linkages' role in fostering firm innovation: an empirical study of Chile and Colombia. Policy Research Working Paper Series 4443.

Merritt, H. (2015). The role of human capital in university-business cooperation: the case of Mexico. Journal of the Knowledge Economy, Springer; Portland International Center for Management of Engineering and Technology (PICMET). 6(3), 568-588.

MingJi, J. \& Ping, Z. (2014). Research on the patent innovation performance of university-industry collaboration based on complex network analysis. Journal of Business-to-Business Marketing. 21(2), 65-83. https://doi.org/10.1080/1051712x.2014.903454.

Morisson, A. \& Pattinson, M. (2020). University-industry collaboration, Lille: Interreg Europe Policy Learning Platform.

Muscio, A. \& Vallanti, G. (2014). Perceived obstacles to university-industry collaboration: results from a qualitative survey of Italian academic departments. Industry and Innovation. 21(5), 410429. https://doi.org/10.1080/13662716.2014.969935.

Myoken, Y. (2013). The role of geographical proximity in university and industry collaboration: case study of Japanese companies in the UK. International Journal of Technology Transfer and Commercialisation (IJTTC). 12(1-2-3), 43-61. https://doi.org/10.1504/ijttc.2013.064170.

Newberg, J.A. \& Dunn, R.L. (2002). Keeping secrets in the campus lab: law, values and rules of engagement for industry-university R\&D partnerships. American Business Law Journal. 39(2), 187-240. https://doi.org/10.1111/j.1744-1714.2002.tb00298.x. 
Nishimura, J. \& Okamuro, H. (2010). R\&D Productivity and the organization of cluster policy: an empirical evaluation of the industrial cluster project in Japan. DRUID Working Papers 10-06, DRUID, Copenhagen Business School, Department of Industrial Economics and Strategy/Aalborg University, Department of Business Studies.

Parkhe, A. (1993). Strategic alliance structuring: a game theoretic and transaction cost examination of interfirm cooperation. The Academy of Management Journal. 36(4), 794-829. https://doi.org/10.2307/256759.

Philbin, S.P. (2010). Developing and managing university-industry research collaborations through a process methodology/industrial sector approach. Journal of Research Administration. 41(3), 5168.

Piva, E. \& Rossi-Lamastra, C. (2013). Systems of indicators to evaluate the performance of university-industry alliances: a review of the literature and directions for future research. Measuring Business Excellence. 178(3), 40-54. https://doi.org/10.1108/mbe-01-2013-0004.

Rampersad, G.C. (2015). Developing university-business cooperation through work-integrated learning. International Journal of Technology Management (IJTM). 68(3/4), 203-227. https://doi.org/10.1504/ijtm.2015.069664.

Ringle, C.M.; Wende, S.; Becker, J.M. SmartPLS, SmartPLS GmbH, Boenningstedt, 2015.

Rogowski, J. Modele miękkie. Teoria i zastosowanie w badaniach ekonomicznych [Soft models. Theory and application in economic studies], Białystok: Wydawnictwo Filii UW w Białymstoku, 1990.

Ryan, L. (2009). Exploring the growing phenomenon of university-corporate education partnerships. Management Decision. 47(8), 1313-1322. https://doi.org/10.1108/00251740910984569.

Rybnicek, R. \& Königsgruber, R. (2019). What makes industry-university collaboration succeeds? A systematic review of the literature. Journal of Business Economics. 89(2), 221-250. https://doi.org/10.1007/s11573-018-0916-6.

Salimi, N. \& Rezaei, J. (2016). Measuring efficiency of university-industry PhD projects using best worst method. Scientometrics, Springer; Akadémiai Kiadó. 109(3), 1911-1938.

Schein, E.H. (2004). Organisational culture and leadership, 3rd edition. San Francisco: Jossey-Bass.

Schofield T (2013) Critical success factors for knowledge transfer collaborations between university and industry. The Journal of Research Administration. 44, 38-56.

Şerbănică, C. (2011). A cause and effect analysis of university: business cooperation for regional innovation in Romania. Theoretical and Applied Economics. 10(563), 29-44.

Sohal, A.S. (2013). Developing competencies of supply chain professionals in Australia: collaboration between businesses, universities and industry associations. Supply Chain Manag. 18(4), 429-439. Available online: https://doi.org/10.1108/scm-07-2012-0228.

Valentin, F. \& Jensen, R. (2007). Effects on academia-industry collaboration of extending university property rights. The Journal of Technology Transfer. 32(3), 251-276.

Vea, R.B. (2014). Industry-academe collaboration for research and development. Discussion Papers DP 2014-10, Philippine Institute for Development Studies.

Wold, H. (1980a). Model construction and evaluation when theoretical knowledge is scarce. In: Kmenta WJ, Ramsey JB (eds) Evaluation of econometric models, Academic Press, Cambridge, Massachusetts, United State, 47-74.

Wold, H. (1980b). Soft modelling: intermediate between traditional model building and data analysis, Banach Centre Publication 6, Mathematical Statistics.

Wold, H. (1982). Soft modeling: the basic design and some extensions. In: Joreskog KG, Wold HOA (eds) Systems under indirect observations: part II, North-Holland, Amsterdam, 1-54. 
$\mathrm{Wu}, \mathrm{H}$. (2017). The essentiality of sustainability and variety for industry collaborations with university partners. International Journal of Advanced Corporate Learning. 10(2), 19-29. https://doi.org/10.3991/ijac.v10i2.7272.

Xia, G. \& Xi, G. \& Jiancheng, G. (2013). An analysis of the patenting activities and collaboration among industry-university-research institutes in the Chinese ICT sector. Scientometrics, Springer; Akadémiai Kiadó. 98(1), 247-263. https://doi.org/10.1007/s11192-013-1048-y. 